\title{
Biogas as Alternate Fuel in Diesel Engines: A Literature Review
}

\author{
N.H.S.Ray ${ }^{1}$, M.K.Mohanty ${ }^{2}$, R.C.Mohanty ${ }^{3}$ \\ ${ }^{1}$ (Dept.of Mech.Engg. GEC, BijuPatnaik University of Technology, Odisha, India) \\ 2 (Dept. of FMP, CAET, Odisha University of Agriculture \& Technology, Odisha, India) \\ ${ }^{3}$ (Dept.of Mech.Engg. CIT, Centurion University of Tech. \& Mgmt, Odisha, India)
}

\begin{abstract}
Bio fuels derived from biomass are considered as good alternative to petroleum fuels. Biogas, a biomass derived fuel can be used in internal combustion (IC) engines, because of its better mixing ability with air and clean burning nature. Biogas is produced by anaerobic digestion of various organic substances such as kitchen wastes, agricultural wastes, municipal solid wastes, cow dung etc., which offers low cost and low emissions than any other secondary fuels. It can be a supplemented to liquefied petroleum gas (LPG) and compressed natural gas $(C N G)$, if it is used in compressed form in cylinders. This paper reviews the current status and perspectives of biogas production, including the purification \& storage methods and its engine applications. Lower hydrocarbon (HC), smoke and particulates emission has been reported in diesel engines operating on biogas diesel dual fuel mode. Here through detailed literature review, the combustion characteristics of biogas in I.C engines are investigated.
\end{abstract}

Key words: Anaerobic digestion, Biogas, Dual fuel, HCCI, I.C engines.

\section{Introduction}

Current energy situation throughout the world and the fact that main resources of energy, such as crude oil, natural gas, coal and nuclear fuel are not renewable give importance to other sources of energy, like hydro energy, solar energy, energy of wind and biogas. Mentioned sources of energy are all renewable, but biogas is particularly significant because of possibility of use in internal combustion engines, which are the main power source for transport vehicles and also commonly used for powering of generators of electrical energy. This possibility of use is justified by biogas properties, which make it convenient for IC engines.

India is largest cattle breeding country; there is abundance of raw material for producing biogas. Also municipal sewage \& kitchen wastes can be used for this purpose. The use of methane separated from biogas as a fuel will substantially reduce harmful engine emission and will help to keep the environment clean. Biogas consists of approximately 50-70 \% methane. It is economical and slurry can be used as organic manure.

In 1981 an effort has been made to use biogas in a converted diesel engine to SI engine by D. J. Hickson. He experienced 35\% less power compared to diesel and $40 \%$ less compared to gasoline fuel. In that year another research was done by S. Neyeloff and W. W. Cunkel. They used a CFR engine and ran it with simulated biogas in different compression ratios. They reached to compression ratio of 15:1 for optimal solution. The lower heating value, corrosive composition and difficulties in transportation of the fuel were main challenges for biogas. In 1983, R.H. Thring concluded that biogas would be attractive just where it is close to production site and he suggested converting gaseous fuels like biogas or natural gas to liquid fuels such as methanol or gasoline.

\subsection{Production}

\section{Biogas as alternate fuel for I.C.Engines}

Biogas is produced by extracting chemical energy from organic materials in a sealed container called a digester. The generation of biogas is the concept of anaerobic digestion, also called biological gasification. It is a naturally occurring, microbial process that converts organic matter to methane and carbon dioxide. The chemical reaction takes place in the presence of methanogenic bacteria with water an essential medium. The anaerobic digestion process, as the name states, is one that functions without molecular oxygen. Ideally, in a biogas plant there should be no oxygen within the digester. Oxygen removal from the digester is important for two main reasons. First, the presence of oxygen leads to the creation of water, not methane. Second, oxygen is a contaminant in biogas and also a potential safety hazard. Due to presence of oxygen, calorific value of biogas becomes low.

\subsection{Composition}

The general composition of biogas is methane, carbon dioxide, hydrogen, nitrogen, water vapour and traces of hydrogen sulphide shown in Table-1. 
Table-1 -Composition of biogas

\begin{tabular}{|l|c|}
\hline \multicolumn{1}{|c|}{ Components } & Amount (\%) \\
\hline Methane $\left(\mathrm{CH}_{4}\right)$ & $50-70$ \\
\hline Carbon Dioxide $\left(\mathrm{CO}_{2}\right)$ & $30-40$ \\
\hline Hydrogen $\left(\mathrm{H}_{2}\right)$ & $5-10$ \\
\hline Nitrogen $\left(\mathrm{N}_{2}\right)$ & $1-2$ \\
\hline Water Vapour $\left(\mathrm{H}_{2} \mathrm{O}\right)$ & 0.3 \\
\hline Hydrogen Sulphide $\left(\mathrm{H}_{2} \mathrm{~S}\right)$ & Traces \\
\hline
\end{tabular}

Source (Karki et al, 2005)

\subsection{Storage}

There are two basic reasons for storing biogas, one is for later onsite usage and the other one is before and after transportation to offsite distribution points. Biogas can be stored at low, medium, and high pressures (Table-2). The density of biogas is approximately $1.2 \mathrm{~kg} / \mathrm{m}^{3}$, which is proximate to air at ambient condition. Hence, it requires a larger volume to store instead in compressed form. The critical pressure and temperature is of $75-98$ bar and $82.5^{\circ} \mathrm{C}$. This indicates that it can change its gaseous phase to liquid phase, when compressed up to the critical state.

Table-2- Most Commonly Used Storage Options

\begin{tabular}{|c|c|c|}
\hline Pressure & Storage device & Material \\
\hline Low $(13.8-41.4 \mathrm{KPa})$ & Water sealed gas holder & Rubber, Plastic, Vinyl \\
\hline Low & Gas bag & Steel \\
\hline Medium $(105-197 \mathrm{KPa})$ & Propane or Butane tanks & Alloy steel \\
\hline High $\left(20 * 10^{6} \mathrm{KPa}\right)$ & Commercial gas Cylinders \\
\hline
\end{tabular}

\subsection{Properties of Biogas used as Fuel in I.C.Engines}

Biogas contains $50 \%$ to $70 \%$ of $\mathrm{CH}_{4}, 5-10 \%$ of $\mathrm{H}_{2}$ and up to $30-40 \%$ of $\mathrm{CO}_{2}$. After being cleaned of carbon dioxide, this gas becomes a fairly homogeneous fuel containing up to $80 \%$ of methane with the calorific capacity of over $25 \mathrm{MJ} / \mathrm{m}^{3}$. The most important component of biogas, from the calorific point of view, is methane. The other components are not involved in combustion process, and rather absorb energy from combustion of $\mathrm{CH}_{4}$ as they leave the process at higher temperature than the one they had before the process. Requirements to remove gaseous components depending on the biogas utilization are in Table-3 (Hingerl, 2001).

Table-3- Requirements to remove gaseous components depending on the biogas utilization

\begin{tabular}{|c|c|c|c|c|}
\hline Application & $\mathrm{H}_{2} \mathrm{~S}$ & $\mathrm{CO}_{2}$ & $\mathrm{H}_{2} \mathrm{O}$ & Siloxane \\
\hline CHP Engine & $\begin{array}{c}<00 \\
\mathrm{ppm}\end{array}$ & No condensation & Yes \\
\hline Vehicle fuel & Yes & Recommended & Yes & No \\
\hline
\end{tabular}

2.4.1-Thermodynamic properties of $\mathrm{CH}_{4}$ at $273 \mathrm{~K}$ and $101325 \mathrm{~Pa}$.

- Specific heat $\mathrm{Cp}=2.165 \mathrm{~kJ} / \mathrm{kgK}$

-Molar mass $\mathrm{M}=16.04 \mathrm{~kg} / \mathrm{kmol}$

- Density $\rho=0.72 \mathrm{~kg} / \mathrm{m}^{3}$

- Individual gas constant $\mathrm{R}=0.518 \mathrm{~kJ} / \mathrm{kgK}$

- Lower calorific value $\mathrm{Hu}=50000 \mathrm{~kJ} / \mathrm{kg}, \mathrm{Hu}, \mathrm{n}=36000 \mathrm{~kJ} / \mathrm{m}^{3} \mathrm{n}$

2.4.2-Properties of Biogas for engine performance.

-The actual calorific value of biogas is function of the $\mathrm{CH}_{4}$ percentage, the temperature and the absolute pressure, all of which differ from case to case. The actual calorific value of biogas is a vital parameter for the performance of an engine.

-The fuel consumption of IC engine using biogas is often specified in $\mathrm{m}^{3} \mathrm{n} / \mathrm{h}$ or $\mathrm{m}^{3} \mathrm{n} / \mathrm{kWh}$. The standard cubic meter $\left(\mathrm{m}^{3} \mathrm{n}\right)$ means a volume of 1 cubic meter of gas under standard conditions $(273 \mathrm{~K}$ and $10132 \mathrm{~Pa})$. The consumption of biogas in actual volume will differ from these data according to the actual conditions of biogas fed to the engine in terms of temperature, pressure and $\mathrm{CH}_{4}$ content.

-Determining of actual biogas consumption is vital for dimensioning the engine.

\subsection{3-Technical parameters of biogas.}

Technical parameters of biogas are very important because of their effect on the combustion process in an engine. Those properties are:- 
- Ignitability of $\mathrm{CH}_{4}$ in mixture with air: $\mathrm{CH}_{4}: 5 \ldots 15$ Vol. \%, Air: $95 \ldots 85$ Vol. \%

-Mixtures with less than $5 \mathrm{Vol} . \%$ and mixtures with more than $15 \mathrm{Vol} . \%$ of $\mathrm{CH}_{4}$ are not properly ignitable with spark ignition.

-Combustion velocity in a mixture with air at $\mathrm{p}=1$ bar: $\mathrm{cc}=0.20 \mathrm{~m} / \mathrm{s}$ at $7 \% \mathrm{CH}_{4}, \mathrm{cc}=0.38 \mathrm{~m} / \mathrm{s}$ at $10 \% \mathrm{CH}_{4}$

-The combustion velocity is a function of the volume percentage of the burnable component, here $\mathrm{CH}_{4}$. The highest value of $\mathrm{cc}$ is near stoichiometric air/fuel ratio, mostly at an excess air ratio of 0.8 to 0.9 . It increases drastically at higher temperatures and pressures.

- Temperature at which $\mathrm{CH}_{4}$ ignites in a mixture with air $\mathrm{Ti}=918 \mathrm{~K} \ldots 1023 \mathrm{~K}$

-Compression ratio of an engine, 'e' at which temperatures reach values high enough for self-ignition in mixture with air $\left(\mathrm{CO}_{2}\right.$ content increases possible compression ratio $) \mathrm{e}=15 \ldots 20$

- Methane number, which is a standard value to specify fuel's tendency to knocking (uneven combustion and pressure development between TDC and BDC). Methane and biogas are very stable against knocking and therefore can be used in engines of higher compression ratios than petrol engines.

- Stoichiometric air/fuel ratio on a mass basis at which the combustion of $\mathrm{CH}_{4}$ with air is complete but without unutilized excess air.

\subsection{Problems to use Biogas in I.C.Engines}

-High $\mathrm{CO}_{2}$ content reduces the power output, making it uneconomical as a transport fuel. It is possible to remove the $\mathrm{CO}_{2}$ by washing the gas with water. The solution produced from washing out the $\mathrm{CO}_{2}$ is acidic and needs careful disposal.

$-\mathrm{H}_{2} \mathrm{~S}$ is acidic and if not removed can cause corrosion of engine parts within a matter of hours. It is easy to remove $\mathrm{H}_{2} \mathrm{~S}$, by passing the gas through iron oxide $\left(\mathrm{Fe}_{2} \mathrm{O}_{3}\right.$-rusty nails are a good source) or zinc oxide $(\mathrm{ZnO})$. These materials can be re-generated on exposure to the air, although the smell of $\mathrm{H}_{2} \mathrm{~S}$ is unpleasant.

-There is high residual moisture which can cause starting problems.

-The gas can vary in quality and pressure.

\subsection{Removal of $\mathrm{CO}_{2}$}

\section{Purification of Biogas for I.C.Engines}

$\mathrm{CO}_{2}$ is high corrosive when wet and it has no combustion value so its removal is must to improve the biogas quality. The processes to remove $\mathrm{CO}_{2}$ are as follows

a) Caustic solution, $\mathrm{NAOH}-40 \% \mathrm{NAOH}+\mathrm{CO}_{2}=\mathrm{NAHCO}_{3}$

b) Refined process, $\mathrm{K}_{2} \mathrm{CO}_{3}-30 \% \mathrm{~K}_{2} \mathrm{CO}_{3}+\mathrm{CO}_{2}=2 \mathrm{KCO}_{3}$

$\mathrm{CO}_{2}$ removal from biogas can be done by using chemical solvents like mono-ethanolamine (MEA), diethanolamine and tri- ethanolamine or aqueous solution of alkaline salts, i.e. sodium, calcium hydroxide and potassium. Biogas bubbled through $10 \%$ aqueous solution of MEA can reduce the $\mathrm{CO}_{2}$ content from 40 to 0.5 $1.0 \%$ by volume. Chemical agents like $\mathrm{NaOH}, \mathrm{Ca}(\mathrm{OH})_{2}$, and $\mathrm{KOH}$ can be used for $\mathrm{CO}_{2}$ scrubbing from biogas. In alkaline solution the $\mathrm{CO}_{2}$ absorption is assisted by agitation. $\mathrm{NaOH}$ solution having a rapid $\mathrm{CO}_{2}$ absorption of $2.5-3.0 \%$ and the rate of absorption is affected by the concentration of solution.

\subsection{Removal of $\mathrm{H}_{2} \mathrm{~S}$}

In physical separation pressurized water is used as absorbent, as both $\mathrm{CO}_{2}$ and $\mathrm{H}_{2} \mathrm{~S}$ are water soluble agents. The water scrubbing method is used for biogas up gradation. The rate of $\mathrm{CO}_{2}$ and $\mathrm{H}_{2} \mathrm{~S}$ absorption depends upon the factors such as, gas flow pressure, composition of biogas, water flow rates, and purity of water and dimension of scrubbing tower.

A purity of $100 \% \mathrm{CH}_{4}$ can be obtained by a pressurized water scrubbing tower with counter current. A reduction of $\mathrm{CO}_{2}$ from $30 \%$ to $2 \%$ in biogas is achieved, when the gas flow rate was $1.8 \mathrm{~m}^{3} / \mathrm{h}$ at 0.48 bar pressure and water flow rate was of $0.465 \mathrm{~m}^{3} / \mathrm{h}$ in a continuous counter current type scrubber. Compressed biogas at 5.88 bar pressure while passed through a $6 \mathrm{~m}$ high scrubbing tower at a flow rate of $2 \mathrm{~m}^{3} / \mathrm{h}$ gives $87.6 \%$ removal of $\mathrm{CO}_{2}$. Solid membrane of acetate-cellulose polymer has permeability for $\mathrm{CO}_{2}$ and $\mathrm{H}_{2} \mathrm{~S}$ is 20 to 60 times greater than $\mathrm{CH}_{4}$, when the biogas flow pressure is maintained at 25-40 bar. Generally the membrane permeability is $<1 \mathrm{~mm}$. For higher methane purity the permeability must be high. Monsanto and acetate cellulose membranes give best separation to $\mathrm{CO}_{2}, \mathrm{O}_{2}$ and $\mathrm{H}_{2} \mathrm{~S}$ than $\mathrm{CH}_{4}$ when temperature and pressure was maintained at $25^{\circ} \mathrm{C}$ and 5.50 bar respectively. Naturally occurred solid Zeolite-Neopoliton Yellow Tuff (NYT) can absorb $0.4 \mathrm{~kg}$ of $\mathrm{CO}_{2}$ per $\mathrm{kg}$ of chabazite at 1.50 bar and $22^{\circ} \mathrm{C}$. During this adsorption process $\mathrm{H}_{2} \mathrm{~S}$ content is removed out. 


\section{Fuels used in I.C.Engines \& Limitations}

There are so many fuels used in I.C. Engines, but they have certain physical and chemical properties. In other words, fuels used in I.C. Engine re-designed to satisfy performance requirements of engine system, in which they are used. The limitations of fuels that are used presently are as follows.

- Gasoline contains many impurities. It has low octane number. All petroleum fuels oxidize slowly in presence of air. The oxidation of unsaturated hydrocarbons result in formation of resinous materials called gum and reduces its lubricating quality and tends to form sludge and warmish on piston and rings. It has less knock resistance as well as energy per unit mass. It has less efficiency compared to other fuels. It has high cost.

-In alcohol, higher latent heat of vaporization reduced charge temperatures before combustion. Alcohols suffer disadvantages of water absorption, corrosive and lubricant incompatibility.

- In LPG, it reduces volumetric efficiency due to its high heat of vaporization. The road sensitivity is very high. It is very corrosive. Response to blending is very poor. It has higher cost of transportation. It has higher cost for conversion kit, installation of extensive.

- In electricity, they use in initially generated power stations that use fossil fuel of nuclear power. There are other problems too. The problem is with batteries in these vehicles. These batteries are quite heavy and life of these is also low. Cost of replacing these batteries is high.

\section{Biogas in I.C.Engine applications}

Biogas can be used in both heavy duty and light duty vehicles. Light duty vehicles can normally run on biogas without any modifications whereas, heavy duty vehicles without closed loop control may have to be adjusted, if they run on biogas. Biogas provides a clean fuel for both SI (petrol) and CI (diesel) engines. Diesel engines require combination of biogas and diesel, while petrol engines run fully on biogas. Use of biogas as an engine fuel offers several advantages. Being a clean fuel biogas causes clean combustion and recesses contamination of engine oil. Biogas cannot be directly used in automobiles as it contains some other gases like $\mathrm{CO}_{2}, \mathrm{H}_{2} \mathrm{~S}$ and water vapor. For use of biogas as a vehicle fuel, it is first upgraded by removing impurities like $\mathrm{CO}_{2}, \mathrm{H}_{2} \mathrm{~S}$ and water vapor. After removal of impurities it is compressed in a three or four stage compressor up to a pressure of $20 \mathrm{MPa}$ and stored in a gas cascade, which helps to facilitate quick refueling of cylinders. If the biogas is not compressed than the volume of gas contained in the cylinder will be less hence the engine will run for a short duration of time.

\subsection{Biogas in Diesel Engine applications}

Biogas generally has a high self-ignition temperature hence; it cannot be directly used in a CI engine. So it is useful in dual fuel engines. The dual fuel engine is a modified diesel engine in which usually a gaseous fuel called the primary fuel is inducted with air into the engine cylinder. This fuel and air mixture does not auto ignite due to high octane number. A small amount of diesel, usually called pilot fuel is injected for promoting combustion. The primary fuel in dual fuelling system is homogeneously mixed with air that leads to very low level of smoke. Dual fuel engine can use a wide variety of primary and pilot fuels. The pilot fuels are generally of high cetane fuel. Biogas can also be used in dual fuel mode with vegetable oils as pilot fuels in diesel engines. Introduction of biogas normally leads to deterioration in performance and emission characteristics. The performance of engine depends on the amount of biogas and the pilot fuel used. Measures like addition of hydrogen, $\mathrm{LPG}$, removal of $\mathrm{CO}_{2}$ etc. have shown significant improvements in the performance of biogas dual fuel engines. The ignition delay of the pilot fuel generally increases with the introduction of biogas and this will lead to advance the injection timing. Injectors opening pressure and rate of injection also are found to play important role in the case of biogas fuelled engine, where vegetables oil is used as a pilot fuel. The $\mathrm{CO}_{2}$ percentage in biogas acts as diluents to slow down the combustion process in Homogenous charged compression ignition (HCCI) engines. However, it also affects ignition. Thus a fuel with low self-ignition temperature could be used along with biogas to help its ignition. This kind of engine has shown a superior performance as compared to a dual fuel mode of operation.

\subsection{Biogas in Dual Fuel Engine applications}

In this case, the normal diesel fuel injection system still supplies a certain amount of diesel fuel. The engine however sucks and compresses a mixture of air and biogas fuel which has been prepared in external mixing device. The mixture is then ignited by and together with the diesel fuel sprayed in. The amount of diesel fuel needed for sufficient ignition is between $10 \%$ and $20 \%$ of the amount needed for operation on diesel fuel alone. Operation of the engine at partial load requires reduction of the biogas supply by means of a gas control valve. A simultaneous reduction of airflow would reduce power and efficiency because of reduction of compression pressure and main effective pressure. So, the air/fuel ratio is changed by different amounts of injected biogas. All other parameters and elements of diesel engine remain unchanged. 


\subsubsection{Modification of diesel engine into dual fuel engine}

Advantages

-Operation on diesel fuel alone is possible when biogas is not available.

- Any contribution of biogas from $0 \%$ to $85 \%$ can substitute a corresponding part of diesel fuel while performance remains as in $100 \%$ diesel fuel operation.

-Because of existence of a governor at most diesel engines automatic control of speed/power can be done by changing the amount of diesel fuel injection while the biogas flow remains uncontrolled. Diesel fuel substitutions by biogas are less substantial in this case.

Limitations

- The dual fuel engine cannot operate without the supply of diesel fuel for ignition.

- The fuel injection jets may overheat when the diesel fuel flow is reduced to $10 \%$ or $15 \%$ of its' normal flow. Larger dual fuel engines circulate extra diesel fuel through the injector for cooling.

-To what extent the fuel injection nozzle can be affected is however a question of its' specific design, material and the thermal load of the engine, and hence differs from case to case.

-A check of the injector nozzle after 500 hours of operation in dual fuel is recommended.

\subsubsection{Performance $\&$ operation parameters}

The performance of diesel gas engines in dual fuel mode has been found o be almost equal to the performance using diesel fuel alone as long as the calorific value of biogas is not too low. The inlet channel and manifold of diesel engine are dimensioned in such a way that at the maximum speed and power output of the engine sufficient air can be sucked in to obtain an air/diesel fuel ratio, which is optimal for operation at this point. When the diesel fuel is reduced and an air/biogas mixture is sucked instead of air alone, part of the air is replaced by biogas. With less air fed to the engine ad an excess air ratio necessarily maintained at $\lambda=1,2 \ldots 1,3$ the total fuel input will be less than the fuel input in diesel operation. As a result in this reduction in both air and fuel, the maximum power output at high speed in dual fuel mode may be less than in diesel fuel operation. This decrease is less significant than in modified petrol engines. For operation in medium and low speeds the air inlet is larger than necessary and allows a relatively larger amount of air/fuel mixture to be sucked in. Hence the power output will not be significantly lower than in diesel operation.

\subsection{Biogas in HCCI Engine applications}

The Homogeneous Charge Compression Ignition (HCCI) concept is a potential for achieving a high thermal efficiency and low Nitrogen Oxide (NO) emission. The HCCI engine with $50 \%$ biogas as a primary fuel and $50 \%$ diesel as pilot fuel gives a maximum $\mathrm{NO}$ of $20 \mathrm{ppm}$ is a major advantage over biogas diesel dual fuel mode. In biogas diesel dual fuel mode the presence of $\mathrm{CO}_{2}$ in biogas lowers the thermal efficiency however, in biogas diesel $\mathrm{HCCI}$ (BDHCCI) mode $\mathrm{CO}_{2}$ reduces high heat release rate. The break mean effective pressure (BMEP) in BDHCCI mode is in the range of 2.5 bar to 4 bar. The smoke and Hydro Carbon (HC) level were also low when the biogas is used as a primary fuel for BDHCCI mode. For HCCI operation the inducted charge temperature is required to be maintained at $80-135^{\circ} \mathrm{C}$, which can be obtained from the exhaust heat. Thus biogas with HCCI engine gives high efficiency and low emission.

\subsection{Exhaust emission}

The exhaust emission contains three specific substances which contribute the air pollution, hydrocarbon, carbon monoxide \&oxides of nitrogen. Hydrocarbons are the unburned fuel vapour coming out with the exhaust due to incomplete combustion. Hydrocarbon also occurring in crankcase by fuel evaporation. The emission of hydrocarbon is closely related to many design \&operating factors like induction system, combustion chamber design, air fuel ratio, speed, load. Lean mixture lower hydrocarbon emission. Carbon monoxide occurs only in engine exhaust. It is the product of incomplete combustion due to insufficient amount of air in air- fuel mixture. Some amount of $\mathrm{CO}$ is always present in the exhaust even at lean mixture. When the throttle is closed to reduce air supply at the time of starting the vehicle, maximum amount of $\mathrm{CO}$ is produced. Oxides of nitrogen are the combination of nitric oxide \& nitrogen oxide \&availability of oxygen are the two main reasons for the formation of oxides of nitrogen. With biogas, co emission levels are low than that of gasoline.

\section{Conclusion}

The study concludes the biogas production from organic wastes, its' composition and properties for use in I.C.Engines. Different techniques for $\mathrm{CO}_{2}, \mathrm{H}_{2} \mathrm{~S}$ scrubbing are discussed, among which water scrubbing is a simple continuous and cost effective method for purification. Attention is also focused for making biogas as alternate fuel in Diesel Engines and dual fueling is recommended to be the best one for biogas CI operation. Drop of $\mathrm{CO}_{2}$ in biogas for dual fueling increases the thermal efficiency. In biogas HCCI mode, the presence of 
$\mathrm{CO}_{2}$ controls the high heat release rate; hence the durability of engine components will not be affected. Therefore it is recommended to use biogas as alternate fuel in diesel engines.

\section{References}

[1] E. Porpatham, A. Ramesh and B. Nagalingam-Investigation on the effect of concentration of methane in biogas when used as fuel for spark ignition engine, Fuel. International Journal, UK, 2007. International Journal of Engineering Research \& Technology

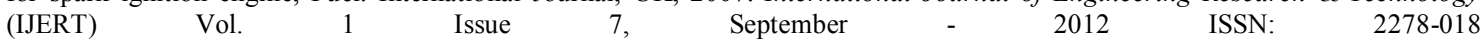

[2] Crookes R.J. Comparative biofuel performance in internal combustion engines, International Journal of Biomass and Bioenergy, vol. 30, pp. 461-468, 2006.

[3] Rittmann BE. Opportunities for renewable bioenergy using microorganisms. Biotechnology and Bioengineering, vol. 100, pp. 203212,2008

[4] Zheng Y, Pan Z, Zhang R, El-Mashad HM, Pan J, Jenkins BM. Anaerobic digestion of saline creeping wild ryegrass for biogas production and pretreatment of particleboard material. Bioresource Technology, vol. 100, pp. 1582-1588, 2009.

[5] Phan Minh Duc, Kanit Wattanavichien, Study on biogas premixed charge diesel dual fuelled engine. Energy Conversion and Management, vol. 48, pp. 2286-2308, 2007.

[6] Jiang C, Liu T, Zhong J. A study on compressed biogas and its application to the compression ignition dual-fuel engine. Biomass, vol. 20, pp. 53-59, 1989 .

[7] Leif G, Pal B, Bengt J, Per S. Reducing CO2 emission by substituting biomass for fossil fuels. Energy, vol. 20, pp. 1097-1103, 1995 .

[8] Henham A, Makkar MK. Combustion of simulated biogas in a dual fuel diesel engine. Energy Conversion and Management, vol. 39, pp. 2001-2009, 1998.

[9] Rao PV, Baral SS, Ranjan Dey, Srikanth Mutnuri. - Biogas generation potential by anaerobic digestion for sustainable energy development in Indiall. Renewable and Sustainable Energy Reviews, vol. 14, pp. 2086-2094, 2010.

[10] Ferrer I, Ponsa S, Vazquez F, Font X. - Increasing biogas production by thermal (700 C) sludge pre-treatment prior to thermophilic anaerobic digestionll. Biochemical Engineering Journal, vol. 42, pp. 186-192, 2008.

[11] Demirbas A. Bio-fuels from agricultural residues. Energy Sources A, vol. 30, pp. 101-109, 2008.

[12] Rittmann, B.E.-Opportunities for renewable bioenergy using microorganisms Biotechnology and Bioengineering.vol. 100, pp. 203-212, 2008

[13] Barik, D. \& Murugan, S. Dept. of ME, NIT, Rourkela, Odisha, India-Production and Application of Biogas as a Gaseous Fuel for Internal Combustion Engines. International Journal of Engineering Research \& Technology (IJERT) Vol. 1 Issue 7, September 2012 ISSN: 2278-018

[14] Hartmann, A. 1989. Anaerobic Digestion Technology. Course on"Energy in Agriculture: General Aspects and Minihydro", Bologna

[15] Turovskii IS, Mathi PK. Wastewater sludge processing John Wiley \& Sons Publication, 2006.

[16] Khenal SK. - Anaerobic biotechnology for bioenergy production, principles and applications Blackwell Publishing, 2008.

[17] Farland MJM. — Biosolids engineering McGraw Hill Professional, 2000.

[18] Steinhauser A. Biogas from waste and renewable resources, dieter doublein. Wiley-VCH, 2008.

[19] Booklets and research materials of Biogas Training Centre on biogas design, Chendu, Sichuan, Chaina.

[20] Hingerl, K. 2001. Scientific ReportESF / PESC - Exploratory Workshop on "The Need for Research towards Biogas Usage in Fuel Cells - A Strategic Question for the European Energy Autonomy" 1-3 April 2001, Steyr, Austria

[21] Modarres RMR, Karim GA. Examination of the dual-fuel engine performance using low BTU gaseous fuels. In: Proceedings of the 13th international conference on thermal engineering and thermogrammetry, Budapest, Hungari, 2003.

[22] Ostrem, K, Millrath, K, and Themelis, N. J. - Combining anaerobic digestion and waste-to-energy 12th North American Waste to Energy Conference, Savannah, Georgia, May 17-19, 2004.

[23] House H. - Alternative Energy Sources-Biogas Production. London Swine Conference- Today's Challenges..... Tomorrow's Opportunities, London, pp. 119-128, April 3-4, 2007. 